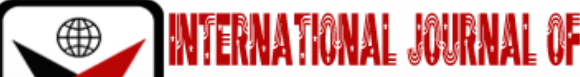

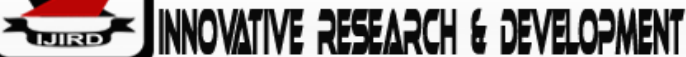

ISSN 2278-0211 (Online)

\section{A Comparative Analysis of Sainthood and Ancestor Veneration in Traditional Religion: A Case Study of Reverend Fr. Michael Cyprian Iwene Tansi}

\author{
Dr. Francis Chuks Madukasi \\ Senior Lecturer, Department of Religion \& Society, \\ Chukwuemeka Odumegwu Ojukwu University, Igbariam Campus, Nigeria
}

\begin{abstract}
:
The veneration of the saints among the Christians and the Ancestor worship among the adherents of African Traditional religion has been seen as a thing that is very sacrosanct in commemoration of both cults in the religious paradigm. The saints in the belief system of the Christians serves as mediators to them through God, while in the religious worldview among the adherents of the African Traditional Religion, the ancestors act as intermediaries in the extraterrestrial or spiritual landscape. This paper focuses on the features or characteristics that show cases their convergences and divergences which evidently supports the theme 'dialogue' among the two world religions using deification theory of Hecataeus which was propounded more than 4000 B.C in relation to where the study of comparative religious scholarship is concerned. This article will investigate these religious steps, using some religious hermeneutic keys, will try to analyse the phenomenon of canonization to show that ancestors and saints are living dead that are venerated by both world religions. This paper also explores those qualities that are used as a yardstick or steps for canonizing Reverend Fr. Michael Cyprian Iwene Tansi as a case study.
\end{abstract}

Keywords: Ancestors, blessed, canonization, Catholics, Christians, saints, veneration

\section{Introduction}

In Christianity the word saint is not an easy word to define or interpret. In communion of saints, saints (Sanctorum) may be understood in Latin as either neuter or masculine; in French the translation becomes equally vague. If neuter, it means holy things, more directly the sacraments, especially the Eucharist. But if masculine, then it relates to persons and communion of saints would signify the establishment of relationship with the saints. But this word also has a two-fold meaning in Christian language. In the scripture and particularly as used by St Paul, it definitely denotes every Christian, considered as already sanctified through his super-natural calling and his incorporation into Christ by baptism. It retains this meaning in a number of Augustianian expressions referring to the society of saints. Gradually, the term reserved for preference to the righteous dead, and at first to the martyrs. Strictly speaking, the influence of the saints in the Christianity has always been strongest on those who live close to them and so could benefit promptly from their life, teaching and example. But their influence goes on after death through the account of them written by those who knew them or knew of them. And as the number of later readers is very much bigger than the number of contemporaries, and goes on growing, it is important to notice that many calls to holiness have been heard and answered through reading the lives of Saints.

This is why Jacques Douillet asserts that 'a saint is person, now dead, whom the Church allows to be publicly venerated' (1958:84). Arguably, there are theological position concerning the saints of the Church and the consequent relation of the faithful to them. Three things in particular help to establish this and they are: (a) that they were actually perfectly holy followers of Christ, who during their life time had fulfilled in the most perfect manner all that God required from them members of his kingdom, (b) that they had as a consequence of this, a special place in the heavenly city, they were Christ's friend in a higher sense than the rest of the elect and enjoyed greater glory and blessedness in heaven, (c) and also, it followed from this that they were patrons and mediators before God and Christ on behalf of the members of the mystical body of the Church and could obtain grace and help by their intercession for the faithful both living and dead. It is on this position that Douillet (1958:76) described the saints as 'more precious than precious stone stones and finer than gold'.

Apart from the above analysis, also the ancestors in African Traditional Religion would be regarded as being on the same level as the saint in Christianity because both have certain spiritual qualities in common that made them to be so elevated therefore, they are the best group of intermediaries between men and God: they know the needs of men, they 
have 'recently' been here with men, and at the same time they have full access to the channels of communicating with God (1977:62-64).

\subsection{Comparative Analysis of Ancestor Cult and Cult of Saints}

Ancestors are nearer to men than spirits and divinities. This is why they are referred to as the living-dead. They also have dual nature and dual language that is they speak the language of the living and the dead that is of the spiritual kingdom. Ancestors can be highly localized, that is when there is ancestor for a whole community or many homes or a whole tribe. There is ancestor for the family. They are ordinary human beings who had once lived and did a lot to improve their various communities, brought enlightenment humanity, greatness and fame their people. In fact, those who had lived an extra-ordinary, holy, heroic, exemplary and mysterious life on earth and were so much highly respected and regarded that when they died, they were elevated from the level of just ordinary human beings or ancestors to that of divinities. They are known as the living dead. The ancestors are still believed to be still living after the death of the person. For somebody to become an ancestor, there are certain qualifications, criteria's or even requirements he or she has to meet like living a good life, raising of children, dying at a very old age and so on. Those who died prematurely are not referred to as ancestor but if they die young while defending their nations, they would be regarded as ancestors after certain rituals must be performed. Nabofa (1994:37) affirms that through the mediation and assistance of the traditional and spiritual elders, 'these kinds of rituals are rigidly and meticulously followed so that they can retain their ancient, ritualistic and spiritual values as revealed and decreed by the divine in order to avoid sacrilege'. Awolalu writes that 'to qualify, such men and women must have lived well, attained an enviable old age before dying, and must have left behind good children and memory' (1976:54). Buttressing this point further, Metuh commented that:

In many others, the funeral rites are absolutely necessary because they regarded as 'rites of passage' by which the dead are installed as ancestors. To these four requirements - old age; offspring; good moral and funeral rites, some societies add a fifth requirement - good death. Death after ripe old age is regarded as good and natural death, and in some places, it is called 'Gods death'. Deaths before this time are regarded as unnatural, for which various explanations are given. There are dome unnatural deaths which are known to be punishments from God for one's sin in his life or in his previous life periods. Deaths by suicide, accident, leprosy, dropsy, small pox, epilepsy etc. are regarded as bad deaths. Victims of such deaths are not given the full funeral rites, and consequently cannot become ancestors (1987:137).

\subsection{Roles of Ancestors}

As the living dead, they have certain roles or functions they perform in the society. They are referred to as the custodian of morality. Africans generally believed that after death, the departed ones enter into the spiritual stage of existence. They are still actively part of the family which they have left physically by death. This belief is held because man is made up both perishable and imperishable nature and immediately man dies, the imperishable part of him which lives on after this physical body vacates the body. Africans believes that the ancestors are capable of living their normal life and maintain their physical features. In fact, because of the significance of the functional activities of ancestors in African cosmology, a special alter or house is designated for them for possible veneration. This is why Mbiti (1970:10) comments that 'after the invocation of the ancestors, the focus of ritual action moved to man house of the homestead. The house was not merely a home for the living, but also a sacred place inhibited by the dead, a domestic space in which the ancestor resided or visited'.

Nonetheless, stand next to the spirits where they are the representatives of the living. In African society, harmony is believed to be made up of the living and the dead and in other to maintain this harmony and pursue a right with the departed spirits, many societies in Africa see to the performance of rites and ceremonies which constitutes a link with the dead. Thus, the ancestors help to maintain coercion in the Society and protect their people from danger. They are overseers of the life and activities of their families. They come to the aid of their people during calamities such as families, draught, pestilence and so on. They are called on any disputes example boundary disputes so that they can make peace between the warring parties. They help their people to ward off evils. They represent their people before those divinities who are the messengers of the supreme God and because they control the characters of their people, they are believed to be the people's morality (Metuh, 1987).

They bless people when they are obeyed and punish them for any misconduct. Therefore, their offspring make sure that they give attention to the observation of the rules and regulations binding their communities as dictated by the ancestors. They took them to a nice feast believing that the ancestors continue with the type of food they were eating while are on earth. With them as a result, the worshippers Amadioha divinity will now give to their ancestors who was a worshipper of Amadioha divinity what they eat while on earth. What the Amadioha does not like would not be given to those ancestors when he was alive and this is what we know as ancestral veneration (Mbiti, 1970). The ancestors depend for their existence upon God. They are not of the same rank and file with God, they have no absolute existence of their own and they must definitely remain importantly connected or linked to HIM. They are intermediaries between God and man. They have become in course of time and space 'the conventional channels through which God is approached' (Idowu, 1973. This had led to the assertion that Africans never approached God directly and that it is only in the moment of distress when all other aids have failed that Africans call on God. In fact, the correct interpretations of the position of the ancestors however are that they constitute a half-way house in which man's soul cannot have what I can call 'complete litmus test' because sufficiency is only ascribed to God. Ancestors are also only means to an end and not ends in themselves, it is only priest craft and the weakness of man's mind that have tried to make the ends in themselves. (Idowu, 1973). John Mbiti described the roles of ancestors succinctly thus: 
They return to their human family's time to time to share meals with them, however, symbolically. They know and have interest in what is going on in their family... They are and guardians of family affairs, tradition, ethics and activities. Offence in these matters is ultimately offence against the forefathers who, in that capacity act as invisible police of the families and communities (1973:83).

Through this kind of 'inner transformation' (Schipper, 1993:171), it is believed that ancestors have been 'admitted into the community of elders' (Ozah, 2006:71). Here, it has been observed that the ancestors act as an agent of social control in any traditional community, no wonder Omoregbe (1993:62-63) argues that they 'provide guides for human conduct indicating certain things or certain ways of behaviour, which should be avoided and other things or ways of behaviour which should be adopted", by 'reminding people of their responsibility to conform to the wishes of their society" (Adejumo, 2013:44). Bloch (1987:278) argues that "because of the calendrical nature of the ritual, this social order became part of temporal and astrological order. This theme of social order is repeated again and again during the ritual". Falola (2003:35) asserts that such ancestral social order invariably 'serving as cultural agents to present African to Westerners while becoming a powerful tool to articulate the ideas of Pan Africanism that united blacks in different countries, also it received a wide affirmation as a socialist ideology based on long-established African values".

Udo (2008:6) argues that 'as character makes for good social relations, it is laid upon every members of community to act in such a way as to promote always the good of the whole body", and 'thereby partly creates the image of orderly antithesis" (Bloch, 1987:287). Ekeke (2013:12) argues that ethics in African traditional society is what a person does in accordance with the established norms which contribute to the welfare of the whole community. Opoku (1978:168) affirms that at the same time, such misdeeds, however, can bring calamity to his immediate family, extended family, his lineage and the entire community, and to avoid the shame that his misdeeds would bring to the entire community, every African [Aguleri person] try as much as possible to live good life. Ogbu (2010:19) affirms that from the injunctions and messages that it is believed to given by the ancestors through the mediation of the spiritual elders, it tries 'to recover social credibility and wholesome impact on local community" of the community and in this way, it solves 'the social and psychological well-being of individuals" (MacGaffey, 1994:243), and by this method also, the ancestors "tells it as it is by asserting its social relevance in the community' (Adejumo, 2013:46). McAdams (1988:217) posits that it is through the ancestors that 'personal and societal solutions enable individuals and societies to take ontological, epistemological, and ethical stands in the face of ambiguity". Young (2003:29) argues that 'it can also be used more metaphorically, as a way of describing how the individual or group can be transformed by changing their sense of their own place in society". Okafor (1994:189) affirms that 'Igbo people turn instruments into metaphors for conveying their feelings and emotions and for giving oral spectrum description'. Turner (1968:21) posits that such sacred musical instrument is regarded as a magnificent instrument for expressing, maintaining, and periodically used in cleansing a secular order of society without strong political centralization and all too full of social conflict.

It is in this wise that Popkin \& Stroll (1981:1) defines ethics as 'a code or set of principle by which men live". The veneration of ancestors, promotes 'social justice, peace, and strivings for harmonious coexistence" (Daniel, 2010:24). Askew (2006:15) idiomatically describes ancestor veneration as 'a silence that echoes loudly", 'which has become a primordial reservoir of moral obligations" (Ekeh, 1975:100). Pinkerton (2011:191) asserts that 'its unique transcendence is paradoxically grounded in an earthly embodiment, and the...is itself, somehow corporeal". It therefore entails that the concept of ethics in traditional African society 'is in living to avoid shame in any family or community (Ekeke, 2013:13).

According to Nzewi et al (2001:93) the concept of encoding ethical lingual text on a music instrument derives from instituting authority voicing in a worldview that processes openly disseminated information for particular, cognitive audience. They argue that the essence is in its imperative transcendental attributes, which empower it to coerce conformity in issues of societal engineering and human management (Nzewi et al, 2001:93). In African Traditional Religion, ancestor veneration provides 'a symbolic system that supported the authority of elders and initiates in the homestead" (Chidester, 1992:11). It is on this positions that Nabofa (1994:19) connected/interpreted this ethical value to the notion that wisdom belongs to the elders and describes the ancestors as 'the voice of the elders which invariably is the voice of wisdom", that 'reminds an initiate of his responsibilities and obligations to his fellow members" (Nabofa, 1994:14). Writing from the context of traditional Igbo society Christopher Ejizu sees the ancestors as those "who assure the traditional Igbo hope of an after-life, as the most being ambassadors / intermediaries of their living members in the spirit-world' (1986:18). No wonder then Idowu (1973, Mbiti, 1977 \& Metuh, 1983) described the ancestors as the living dead.

\subsection{Qualification of a Saint}

Biblically, the word saint is used as an umbrella appellation for believers, just as the word 'Christian' is used also to identify the followers of Christ. It can also be used to denote holiness. The Oxford English Dictionary defines 'saint as follows (a) a holy person (b) person, who having died, is among the blessed in Heaven (c) person who has been declared by the Church to have won the holy living on earth, a place in heaven and veneration on earth' (Hornby :1304).

Now the question to answer is: Does everyone who goes by the title of 'saint' end up dying a saint? Obviously, not at all because Jesus said in the book of Mathew (7:21) that:

'Not everyone who says to me, Lord, Lord shall enter the Kingdom of heaven, but he who does the will of my father who is in heaven'. Also, among the saints as used for all believers in the Bible, 2 Timothy (2:20) says that: 'In a great house there are not only vessels of gold and silver but also of wood and earthenware, and some for noble us some for ignoble'. Actually, this verse explains the reasons why the Church takes time to judge and determine those of her Children who, by their excellent love, good and heroic life 'holy living' were consecrated and noble use in the hands of their master 2 Timothy (2:21) and hence, recommend them as models to be imitated by the faithful Philippians (3:17). 


\subsection{Authority to Judge in the Bible}

The saints (human, believers) will judge the word and even the angels during the last day. In 1 Corinthians 6 (1-3) it asserts that believers (saints) shall indeed judge the world (fallen) angels. Indeed, the Church believes this and this is actually guided by it. Now the questions are: Why will believes (saints) be permitted to judge the whole world and angels? Are they not usurping the prerogative of Almighty God? In fact, by no means in 1 Corinthians (3:9) it says that 'we are God fellow workers'. Also, in the book of Mathew (16:19), the Bible shows whose authority the Church of Christ shares with regard to judging among her Children in the following passages: 'I will give you the Kingdom of heaven and whatever you bind on earth shall be bound in heaven and whatever you lose on earth shall be loosed in heaven'. Again, the Holy Spirit speaks through St Paul in 1 Corinthians $(5: 12)$ thus 'is it not those inside the Church you are to judge?' Furthermore, the apostle St Paul actually demonstrated the authority as he tells the Church in 1 Corinthians 5 (3-5) thus 'I have pronounced judgment in the name of the Lord on the man who did such a thing. Deliver this man to Satan for the destruction of the flesh, so that his Spirit may be saved in the day of the Lord Jesus'. Saint Paul explains and writes further to young ebullient Timothy in 2 Timothy 4 (7-8) thus 'I have fought the good fight, I have finished the race, I have kept the faith. Henceforth, there is laid up for me the crown of righteousness which the Lord the righteous judge will award to me on that day...' Here, St Paul pronounces judgment even on himself in the same way he led the Church in Corinth to pronounce judgment in the name of the Lord 'on the man who has done such a thing' (1 Corinthians, 5:3), yet acknowledging the Lord as the righteous judge, just as the phrase 'in the day of the Lord Jesus' (1 Corinthians, 5:5), shows that St Paul was not aware of God being the ultimate judge. In the case at hand, the Church of God id saying: Deliver Father Tansi to the eternal beatific vision of God, for he has fought the good fight, he has finished the race, he kept the faith. Henceforth, there is laid up for him the crown of righteousness which the Lord the righteous judge will award to him on that day - this line is in line with (2 Timothy, 4:8).

\subsection{Why Saints are Beatified and Canonized after Death?}

Actually, sainthood as considered or seen from the merit and reward perspective has to with the entire life span of the person in question, which is better assessed after he or she has kicked the bucket. For clearer understanding of this, let us consider immediately the following scriptural verses. The gift of salvation is in earthen vessel (1 Corinthians, 4:7), and hence capable of breaking half way through life, if not handled with care. To this end, the Holy Bible says that 'work out your salvation with fear and trembling' (Philippians, 2:12). Not that I have already obtained this I am perfect, but I press on to make it my own, because Christ Jesus has made me his own (Philippians, 3:12-15). All things being equal, 2 Timothy (2:5) affirms that 'an athlete is not crowned until he finishes according to the rules'.

However, a critical analysis of the apostle's attitude above, while still running the race and so on, his pronouncement after he finished the race when he said 'I have fought the good fight, I have kept the faith...'. The apostle could only talk about the crown because he had come to the end of the race for he revealed 'I am ready to be sacrificed' ( 2 Timothy, 4:6). Consequently, further interrogation into this is the emergency of the fact that a saint is not fully made, 'has not obtained it', until, in line with biblical verses, he finishes according to the rules (2 Timothy, 2:5). This is the reason why the Church of Christ, empowered by the Holy Book, as we have argued earlier, beatifies and canonizes her deserving sons and daughters after death. To serve as an example for the faithful and to encourage others to be good Christians.

\subsection{Saints in Heaven}

In the past and even at present, the Church had had to grapple with pseudo - religious fundamentalist who, twisting and mis-interpreting the Holy Book of the Christians, reveled in causing disaffection and division among Christians. They preach heresy by saying that the cults of saints are not in existence and that they are in heaven. In fact, the Church is readily vilified, even by the society secretaries and club secretaries, who are powered by refractory fanaticism as the strain at the leash for recognition or popularity thereby forcing their ambition on the Bible. This actually prompted Saint Paul to write that:

I appeal to you, brethren, to take note of those, who create dissension and difficulties in opposition of the doctrines which you have taught; avoid them. For such persons do not serve our Lord Jesus, but their own appetites and by fair and flattering words they deceived the hearts of simple minded (Romans, 16:17).

Now, in considering the assertion by some people with grasshopper mentality that saints are only restricted to the living but having nothing in common to do with heaven and the dead. The Book of Hebrew 12 (12-22) critically refutes that:

But you have come to mount Zion and to the city of the living Gog, and to innumerable angels in festal gathering and to the assembly of the first-borns, who are enrolled in heaven and to a judge who is God of all and to the Spirits to just men made perfect and to Jesus, the mediator of a new covenant.

Analytically, the above verses, as clear as crystal, shows that the saints being referred to here are those already in 'enrolled in heaven'. The following phrases like 'Heavenly Jerusalem', 'City of the living God', 'innumerable angels in festal gathering' would bear out a simple truth / interpretation the whole scene is that of heaven. Equally, the saints who constitute 'the Spirits of just men made perfect' are also the first-borns enrolled in heaven. Now, the question is: why first born? Because others like them, who are still living would be born into heaven subsequently. This also agrees with Revelations (6:9-10) which says where more are being awaited to enter heaven through martyrdom. To further expatiate more that there is heaven even as the universe goes on, Saint Paul speaks of 'every family in heaven' (Ephesus, 3:15). The Holy Bible refers to the saints as 'those who have washed their robes and made them white in the blood of the lamb therefore are they before the throne of God, serving Him day and night' (Revelation, 7:13-15). The writer of Saint Luke's 
gospel calls paradise 'Abraham bosom' where Abraham and Lazarus are, as spirits of just men made perfect (Hebrew, 12:23).

In the other way round, the rich man was seen to ask for Abraham's help, to show that they are in understanding, intelligence, communication and even interaction beyond the grave. Moses and Elijah, belonging to the saints came from heaven bringing heavenly glory and aura which actually enthralled Peter so much so that he prayed that they make three booths at the mount of transfiguration (Luke, 9:28-35). Consequently, saints are seen making a prayer petition to God in heaven, thus praying to him (God) to avenge their death on those still living in the world, who had killed them for the sake of the gospel (Revelation, 6:9-10). Also, Saint Paul had the notion of sainthood in heaven - that to depart the body is to be with Christ, when he wrote thus 'I want to be gone and be with Christ which will be very much the better, but to stay alive in this body is more urgent need for your sake (Philippians, 1:23-24).

\subsection{Praying through the Saints}

By this I mean intercession of the saints, which Christians occasionally or usually ask for, in their prayer. This is actually derived from the communion of saints (check out the Apostles' creed), in which the Church triumphant - the saints or faithful departed, now in heaven and the Church prayer warriors of the body of Christ still fighting towards the upward goal or achievement here on earth, are known to be one in Christ. The only discrepancy between the two is that while the one has put on immortality, the other one is still in the mortal from - both united by their common faith and belief in Christ.

This very great bond transcends the distance interventive relationship of interaction between heaven and earth, so that those who really believe in life after death petition the Church triumphant to 'pray for us' (Colossus, 4:3; 1 Thessalonians, 5:25; 2 Thessalonians, 3:1) and so on. In the same way they would pray for the Church in other parts of the world - all through Christ. Those are myopic minded think that by praying through the saints, many are misled or misguided to believe that the Lord Jesus is displaced by the interceding saints. This is nothing but fallacy. In short, all prayers, whether offered by the Church prayer warriors or the Church triumphant, go through Christ according to Christian Catholic believes system. The Holy Bible has it that 'by prayer and supplication... make your request to God' (Philippians, 4:6).

Now, another vital question is: Why do people make their request known to man instead, through prayer petition, thus allowing an intermediary or a mediator? To take position of Christ, again the Lord Jesus is interceding on behalf of the faithful in heaven (Hebrew, 7:25), your evangelist or even your pastor intervene. So, you can clearly Jesus supreme mediatorship or intermediaryship is simply a far cry from an ordinary intercession, either by saints in heaven or by the Church prayer warriors. These two should not be confused.

Apart from this, if the prayers of the religious, who are still prone to imperfections, avail much (James, 5:16) much more will the prayers of the redeemed, who no longer see dimly (Corinthians, 13:12) but are before the throne of God (Revelation, 7:15), be of great effect. Strictly speaking, the communion of saints or unity of the Church prayer warriors and the Church triumphant can be better appreciated whole heartedly, when all and sundry come to realize that the festal train in heaven (Hebrew, 12:22-23) and rejoicing to their festive mood, when a single sinner repents on earth (Luke, 15:7). Now, another significant question is: Why should the heavenly hosts notice one single repentant sinner admits billions upon billions of people on this, if not very good concern for the salvation of the living? Really, it is this same 'feast gathering' that Saint Paul waited for in the book of (Philippians, 1:23-24) as we saw previously. It is our desire / prayer that we be saved. These desires normally meet in the communion of saints.

It is therefore empirically clear that 'pray for us' as being addressed to the saints in heaven, evokes the sum of total power of Christian support, the bond of the mystical body of Christ - a type of spirit de corps. And even rather than detract from the intermediaryship or mediatorship role of Christ so to say, it brings to every dick and harry his redemptive accomplishments. In a nut-shell, whenever Christians ask for the intercession of the saints in heaven, they actually believe with the Lord Jesus and the Bible in the concept of life after death, that God of Abraham, Isaac and Jacob is not God of the dead, but of the living (Mathew, 22:29-33). Cyril Ofili (1998:27) concludes that 'it is therefore clear that the statement prays us as addressed to the saints in heaven, evokes the power of Christian solidarity, the bond of the mystical body of Christ - a form of esprit de corps. And rather than detract from the mediatorship role of Christ, it brings to fore his redemptive accomplishments'.

\subsection{Convergences and Divergences of Ancestor Cult and Cult of Saints}

For the fact, that the ancestors in African Traditional Religion and saints in Christianity has been described by different visionary scholars as the living dead and both play the role of intermediaries in the two world religions then one can firmly say that they converge there. But in the area of its divergence, it is observed that in African Traditional Religion, once an adherent that qualifies to be ancestor dies, he or she automatically becomes an ancestor without undergoing any other process or processes. While, in Christianity, before a person can be acknowledged and deified as a saint, he or she must have undergone the rigours of the processes laid down by the Church before becoming a saint.

\subsection{Steps to Sainthood}

A genuine call to holiness is a call for all Christians. It is the Christian belief that all through baptism we are all Children of God. We become adopted sons and daughters, a King, prophets and equally priest. Genuine holiness is never reserved for any particular people, colour, race or specific generation, even at death; we go back to our creator, the religious to eternal Kingdom and everlasting happiness. Strictly speaking, that the Christians recognize certain saints in heaven is not partial or sectional but rather Godly. It does not mean that others are in hell fire. In fact, it is an act of 
manifestation, chosen by God himself to teach, show correction or even bestow his people graces through the saint in question. For Reverend Fr. Cyprian Iwene Tansi to be canonized 'saint' by the Church, certain processes are involved. It is not an easy task because of the infallibility of the Church.

Now, let us ask this question: What does it take to make Tansi a saint? The Church has chosen Tansi among those who have followed conscientiously, consistently and diligently the good exemplary life of our Lord Jesus Christ and actually gave outstanding testimonies to the Kingdom of heaven by way of martyrdom or by a heroic virtuous life. The process of canonization at times takes ten years and sometimes up to twenty to fifty years or more after the person in question has died. The process of canonization is basically sub-divided into four steps:

\subsubsection{The Diocesan Information Processes}

This is a process of inquisition done by the diocesan bishop through a diocesan tribunal. The competence of this tribunal is to build up historical facts on the life, work and virtues of the person unto whom there is an evidence of a popular fame of sanctity. The diocesan bishop is the Chief Judge of this tribunal; otherwise, he may delegate his powers to another person.

\subsubsection{The Vatican Sacred Congregation Process}

There is a Vatican office headed by a Cardinal entrusted solely with the causes of saints. When the acts and documents of the diocesan tribunal reach the Vatican, this office, the sacred congregation for the causes of saints, has to receive the acts and the documents, then study them in full details and finally expresses its judgment. It is also the duty of this office to deal with those issues pertaining to the authentication and preservation of relics.

\subsubsection{Beatification}

If the judgment of the sacred congregation for the causes of saints is favourable, then the Holy Father - the Pope will be requested to beatify the servant of God. In a special solemn ceremony, the Holy Father will proclaim the deceased blessed, which means a tentative recognition of the deceased extraordinary sanctity. From that moment, the blessed can begin to have some cult and be prayed to in public.

\subsubsection{Canonization}

After the beatification, sometime is allowed. Some more miracles, at least one miracle accredited to the servant of God is recorded. Then, in another public solemn ceremony, the Holy Father proclaims the venerable servant of God - a saint. At this time, he can be honoured at the Alter and publicly venerated by the universal Church (Nwosu, 1998: 8-9). Consequently, in the course of beatification as a process of canonization, miracles are necessary and allowed or considered in between the period. According to Nwosu (1998:9) again, 'a miracle is a perceptible fact, performed by God, beyond all the forces and laws of nature'. These wonderful miracles performed by God's grace through the intercession the servant of God after their death ascertains their sanctity, with divine power. This is the reason why the Church holds in great esteem this supernatural element in the causes of beatification. Frankly speaking, Fr. Tansi's case is highly considered here because before he was accepted in the causes of saints, there was evidently a miracle of perfect cures of incurable or serious disease of an organic nature obtained following invocations to the servant. According to Trinitas 'the approved miracle which cleared the way for the beatification of Fr. Tansi involve a 19-year-old girl Philomina Udezuo Emeka who was suddenly, completely and permanently cured of retroperitoneal fibrosis through the intercession of Tansi (1998:1)'. Although, Fr. Tansi has not been fully canonized a saint but he scaled through the first three processes before canonization but there are series of miracles that have taken place before or after his beatification (News Letter, 1983 \& News Letter, 1983).

\subsection{The Roles of Fr. Tansi in the Development of Women}

Fr. Cyprian Michael Iwene Tansi from the time of his ordination till he became a cloistered monk and as Fr, Mark Hartley (1954) cited in Isichei (1980:102) puts it 'he was just an ordinary monk, monking about' in England, initiated various pastoral techniques of taking very good care and ministering to individuals and groups particularly women and minors within the ambit of the Church. Among the role he played in the development of women within the Church was his unrelenting effort to secure solid Christian families stands. He set great store on couples beginning their new marital life on the bases of chaste wedlock (Arinze, 1973). He therefore established institutions where engaged ladies were housed before their wedding. There, they were not only safe from pre-marital sexual relationship with their fiancés, but also from other temptations. They especially learnt Christian families' upbringing and moral building. In ministering to such women as a group, he actually opened 'a floodgate of creativity and injected it into the traditional rhythms they inherited from their forebears" (Burns, 2005:307). This he did creating series of opportunities for advancement of women which would be kept for posterity. There are three categories of women he attended to according their age group, namely: the young unmarried girls, the young ladies not yet married in the Church but living with their various husbands and the married women.

Fr. Tansi actually contributed immensely to the development of women because he was the person who singlehandedly started the Mary League for the young unmarried girls and equally the Saint Annes Society for married women which are still in existence in different parts of Nigeria till date (Idigo, 1977:109). In fact, the two religious organizations up till date still form part and parcel of basic teachings for Catechetics in Igbo speaking areas in eastern Nigeria. One significant question people normally ask is: why did Fr. Tansi dedicated so much his time and energy to training of 
women? One school of thought believed that it is because of the way the beloved mother died that actually made him to dedicate himself to women development. According to Gregory Wareing:

In 1922 Michael's mother died in tragic circumstances. By village standards Ejikwevi was now an old woman. Following on the sudden deaths of several youngsters she was pointed out by the medicine man as the one who was changing her way out of death. Religious custom held her bound to drink poison and die. This she did' (1998: 3).

Nonetheless, Fr. Tansi proved them wrong by attributed his dedication on women to negligence in the society. Basically, from the articulated letter he wrote to one of his spiritual daughters he asserts 'a nation that would look down on her women or treat them in any way other than as noble and fair creatures of God, that nation is doomed to ruin' (Trinitas, 1998:15). He also believed that women in diaspora especially in Nigeria are talented and creative like their men folk and for that singular reason therefore they should have a part to play in the development of this great nation. That is why he echoes thus 'let it be quite clear to you all that the fate of Nigerians is their hands at least in great part. The ruin of this dear country is in theirs, the rising of this country, to a status worthy of honour is also theirs' (Trinitas, 1998:15). He equally realized that some men turned down the idea of Christian marriage because of philosophy of monogamy (Sofola, 1973).

So as a parish priest who has that vision and passion for the Church, he knew that for the Church to create a conducive ambience that would foster Church marriage, the women's status quo in the society must empirically undergo some kind of 'surgical and revolutionary social change'. The first in line of his tactical objectives is that women must be educated so that they would know their right in the society. Actually, the women in the parish responded positively and before the society knew what was happening, they have become a formidable force to be reckoned with in their different families and their various communities at large. Also, cultural, he introduced the boys and girls to perform traditional dances. As Idigo states that 'he got the boys and girls to organize their own teams, and dance to their hearts content' (1997:81).

Upon all these efforts he made to see that he aided in the aspect of developmental of women, there are still certain problems he faced in training women in those early days. The traditional Igbo society practice polygamy and even extended family system and in this regard, women in this society traditionally had no locus standi to equate themselves with their male counterpart (Sofola, 1973). That is why Tapper (1991:104) asserts that inequality of status does not preclude able women from wielding considerable power within the household. Koskoff (1989:13) also observes that across culture women sometimes 'connive' with these notions. This concept of gender has been a serious discourse for some time which made Aluede (2005:58) to assert that such roles structure our choices and guide our behaviour in an acceptable manner within the community we operate. However, gender issue is a condition of being either male or female and in this wise, Nfah-Abbenyi (2005:260) argues that men and patriarchal ideologies control women's reproductive and sexual capacities, and that as a result, women are trapped by their reproductive anatomy and by a dogma of compulsory heterosexuality. In fact, in Nigeria, a typical Igbo man, in an Igbo society attaches much significance to this concept of gender inequality and this apparently is very noticeable in situations where a woman does not have a male child for the husband, she of course knows that her position is being threatened (Nwokocha, 2007:230). Metuh (1987:188) asserts that 'a woman who cannot or has not given birth is a social misfit and if she has never conceived, she is openly ridiculed and told that she is not a woman". Nwoye (2007:390) argues that 'an African marriage experiences a sense of disorder and distress where the above process of positive evolution in a marriage fails to place".

However, Fr. Tansi knew actually what the position of these women was and decided to train them, although he encountered series of antagonism from the indigenous people in various Igbo communities in those days during the training process but later, he excelled.

\subsection{Achievements of Fr. Tansi}

When Jesus Christ began his ministry in the world and firstly introduced his humble self as coming from Nazareth and of a carpentry ancestry, then there was disbelief that 'nothing good will come out of Nazareth'. The people wondered: is it possible that anything of such good, magnitude or great value would emanate from or emerge from such a background? One could say the same of Blessed Fr. Cyprian Michael Iwene Tansi. His village, Aguleri which was described by Isichei as 'perhaps more than any other place, was the cradle of Igbo civilization. A long history, encapsulated in mythology recalls a man called Eri, sent from God, who lived there' (1980:2). This town first entered the map of the early missionaries just because it was a river port in the neighborhood of Onitsha. The Holy Ghost congregation actually started their incursion of eastern Nigeria in 1885 from Onitsha. These Holy Ghost Fathers were men of courage, and their unrelenting effort and dedication to the cause of evangelism - the kingdom of God could be equated with that of Pope John Paul 11 'whose age and physical disability have not apparently constituted obstacle to carrying out his papal destiny of leading the Church into the next millennium' (Ojigbo,1998:15). The Holy Ghost missionaries moved by experimentation by building a Christian village at Aguleri. According to Obi et al 1985:52) 'in taking possession of the station at Aguleri, our first concern was to build a Christian village'.

It is interesting to note here that before they penetrated into the community there was series of consultations with Onyekomeli Idigo who was the natural leader of the community then. After such series of negotiations with the officers of the company, a trading pact was signed and a base was established at Odene Eziagulu and the presence of the white men actually resulted in a tremendous growth of the influence of Onyekomeli Idigo and his authority waxed stronger (Idigo, 1990:11). According to Obi the Aguleri mission owed its foundation to the courageous and generous initiative of King Ogbuanyinya Onyekomeli Idigo, who invited the missionaries at Onitsha, as early as 1888, to come and settle at Aguleri. He was already used to seeing white men for the Royal Niger Company had a base at Aguleri. This may explain how he got to know of the Catholic mission station at Onitsha' (1985:43). Also, Idigo concurs that: 
In 1888 Ogbuanyinya Onyekomeli Idigo of Aguleri, when he was acquainted with the news of the arrival of the Evangelists at Onitsha twenty-eight miles away, invited the missionaries to his town. A detachment of the congregation of the Holy Ghost was then drafted to Aguleri. This was the first time the messengers of God set their foot in Aguleri. A permanent settlement was not affected at their first arrival. A couple of visits and negotiations with the chief and elders transpired before the missionaries finally settled in the town, in a particular village called Eziagulu (1977:15).

Buttressing this further, Onunwa comments that:

One outstanding noble patron was Chief Idigo of Aguleri who was said to have invited the Roman Catholic Mission in 1887 two years after they had established in Onitsha. It was through him, in spite of the difficulties he encountered after his conversion, that the R.C.M. made a strong break-through in Aguleri. The personal contacts with the Chiefs made a strong impact on their subjects. Although missionary records are silent on the major motivations of some of the Chiefs who invited the missionaries who offered them patronage and protection, it is undeniable that there might be some genuine desire for Christianity in some of them while others who saw the enviable position Onitsha had reached because of European presence, decided to invite the white missionaries. The alliance method was adopted by different missionary groups in different places starting from Onitsha and Aboh. It was not peculiar to any particular mission (2002:74-75).

Onyekomeli Idigo married many wives and had many children but most of them died in their infancy and this loss were unbearable to him (Idigo, 1990:48). In another dimension, Isichei (2004:7) asserts that because African traditional religious systems tend to be shadowy and unattractive, many early converts were drawn to Christianity by the promise of eternal life. She affirms that Idigo, the first King of the Igbo polity of Aguleri, was a late-nineteenth-century prosperous and successful ritual specialist, became a Christian because his powers were unable to preserve the lives of his children (Isichei, 2004:7). Ekechi (1976:1191) regrettably argues that 'for Isichei to say that Chief Idigo of Aguleri embraced Christianity because he was alienated from traditional religion is tenuous; and her oblique acceptance of obsolete detribalized Africa is unacceptable.

Nonetheless, in 1890, Onyekomeli Idigo was baptized along with most members of his family, having renounced all but one of his wives and after being baptized, he changed his name to Joseph and later sent some of his children to be educated at Onitsha (Obi et al, 1985:47). Strictly speaking, through this method Ogbuanyinya Onyekomeli Idigo was highly committed and charged to the cause of the New Aguleri Roman Catholic Parish that he eventually left his village and quickly joined the white Missionaries in what became a 'Christian village" (Obi,1985:50) at the same site of the present Catholic Pro-Cathedral (Idigo, 2001:125). According to Obi (1985:54) 'some solid Christians emerged from this Christian village - Rev. Father Michael Iwene Tansi who was a product of the Aguleri Christian village'.

This involved the separation of Christians from non-Christians and in setting them in a location different from where Christian laws and tenets would constitute their rule of life. In fact, the missionaries failed to settle account with the force of inherited tradition, Igbo solidarity encased in the so-called extended family system. That experiment in physical separation now lies in ruins. Although, some strong and unwavering Christians emerged from this Christian village of which 'Rev. Fr. Michael Iwene Tansi was a product of the AguleriChristian village' (Obi et al, 1985:54). All things being equal, Tansi a first-generation Christian was completely seized firmly with this concept of separation from the world. He cherished and hungered to live in solitude where he could be with God alone and completely. After all, the ambition of Christian mysticism is the contemplative life of beaming fruit in the pre-emptive beatific vision where we see or confront the divine face to face (Ojigbo, 1998:15). A very big question from the biblical verse is: 'what will if profit you if you gain the whole world and lost your own soul?' (Matt, 16:26) is a gospel verse which is not to be disobeyed that has actually and sincerely persuaded and continues to persuade people to give up poverty. Thus, after Fr. Tansi's ordination to the priesthood and some pastoral apostolate in the Onitshe Ecclesiastical Province, he was not discouraged by the fact that Eastern Nigeria was still pagan territory that is in dire need of foreign missionaries' (Ojigbo, 1998:).

Later, he got permission to pursue his vocation in the monastery. Nevertheless, the present, the world interest on this already forgotten monk 'monking about' (Isichei, 1980: 102) bears serious testimony to the genuineness of his choice of vocation in a situation that would have been given an interpretation as flight from incumbent responsibility (Ojigbo, 1998:15). Strictly speaking, nowadays people are highly fascinated by 'secular Christianity' and intrigued by the Nazi resistant fighter, Dietrich Bonhoeffers's philosophy of a 'religionless Christianity' (Oshitelu, 2002:83-86). In the time of Fr. Tansi and his contemporaries, the understanding of holiness was unambiguous namely: fly away from the world, go to the desolate area and live, and deny yourself of worldly pleasures. Obviously, his quick response and reaction to the call of the divine or holy of holies was resolute and decisive. He entered the monastery to devote himself to pray with a positive, forceful, proactive and undivided attention. He also entered the monastery to practice what could be described as practical Christianity and it was unedited scriptural Christianity which was a scripture without exegesis (Ojigbo, 198:).

\subsection{Brief Historical Paradigm of Aguleri Origin and Migration}

Consequently, there is a theory in circulation about Fr. Tansi's birth place. If really this theory is validated as true then he could be a descendant of one the lost tribes of Israel. Strictly speaking, no one actually knows when Aguleri was incepted as a town but the history of Aguleri may have dated back to the early part of civilization and modernity in Nigeria (Idigo, 1990:3). Thurstan Shaw argues that 'one of the fascinating things about archaeology is that since it is rarely possible, in a logical sense, to give a watertight proof of anything, the interpretation of archaeological data is always a matter of balancing possibilities' (1975:503). Michael Idigo affirms that 'since there were no written records, the dates of events, origin and migration of Aguleri people depended heavily on time-honored legends, oral tradition, recent archaeological discoveries and excavations' (1955:3). Recent carbon dating of an excavated site in Aguleri showed that it had been continuously inhabited for about 5000 years (Omoregie, 1989). The origin of Aguleri people would be linked to the migration of Igbo race to this present Nigeria as a nation who are believed to have been among the 'Hebrew patriarchs' 
(Bright, 1981:23) through Gad one of the sons of Jacob that migrated from Mesopotamia and the father of Eri. John Bright concedes that although as widely held, this position has been 'vigorously contested in recent years by certain scholars who maintain that the patriarchal narratives are more or less imaginative literary creations of a much later date with no appreciable stream of oral tradition behind them, and without real historiographical intention or historical worth' (1981:73).

According to traditional and popular legend on the history of Aguleri, Victor Eyisi (2010:3) comments that Eri and his entourage continued their migration southward until they finally settled at a place known to us today as Aguleri, the ancestral home of the Igbos around 1303 B. C. at the confluence of two rivers Ezu and Omambala - a tributary of the great River Niger. He argues further that in Aguleri today, there is a place called Agbanabo-Ezu-na-Omambala [the confluence of the rivers, Ezu and Omambala, which form the Anambra River]. Here it is believed, Eri landed with his entourage before moving to settle in $\mathrm{Obu}-\mathrm{Gad}$, Aguleri. The $\mathrm{Obu}-\mathrm{Gad}$ [that is Gad's memorial palace] is apparently visible and this remains a tourism site in Aguleri town (Eyisi, 2010:3-12). Igwah et al (2014:1) argues that this particular place is very symbolic because it is believed that 'it was at this point that Eri had a divine revelation that they had reached their ordained place of settlement'. Isichei (1976:4); Onwuejeogwu (1981:22) \& Xrydz-Eyutchae (1986:11) equally affirm that it is 'from this point each settlement pursued its own separate existence and development, owing allegiance to Aguleri, where the collective ancestral temple of Eri still stands to this day'. Aguleri is a community of 'one people - one destiny' (Arkin, 1989: xi).

However, according to Madukasi (1999: 69) 'Aguleri people speak an Igbo dialect with a kind of elision that is not easy to follow or understand, and for this theory to be disclosed one has to try to play on the tonal sound of their names and even their local dialect when actually pronounced with original and unrefined Igbo cadence'. Before the truthfulness and the authenticity of this claim is confirmed, we are fully justified in claiming Fr. Tansi to be a full-blooded Igbo man from eastern Nigeria who honestly and genuinely responded to the divine call and gospel challenge with courageous and unrestricted self-donation (Ojigbo, 1998:15).

Empirically, it is amazing that such a servant of God should emerge and emanate from Igbo, a race of boisterous, restless and pragmatic mainly businessmen and industrialists whose driving positive force is always to be somebody (Ojigbo, 1998:15). No wonder Ikeanyibe (2001:30) describes the Igbos as the 'resilient Nigerian Hebrews', who were 'prevented from living legally, and prevented from surviving illegally" (Ojukwu, 1998:76). Buttressing this further, Enobabor Idahosa, a Bini, attests that 'the Igbo man has come to earn my respect because of his tenacity to survive. He seems to convert each of his set back into strength immediately. Thus, the Igbo are like mysterious animals who feed as they are being shot: Anu ana agba egbe ona ata nni' (Ikeanyibe, 2001:31). The appearance of this servant of God - Blessed Fr. Tansi according to Ojigbo (1998:15) 'argues for the stretching of this pre-Christian expectation of excellence into the Christian imperative of 'be ye perfect as your heavenly father is perfect' (Matt, 5: 48).

\section{Conclusion}

For the fact that the ancestors in African Traditional Religion and the saints in Christianity have been described by different visionary scholars as the living dead and that both play the role of intermediaries in the two world religions, therefore one can sarcastically and firmly say that they converged there. But in the area of its divergence, it has been observed that in African Traditional Religion, once somebody that qualifies to be an ancestor dies, he automatically becomes an ancestor once the full burial rites have been consummated without undergoing any other process or processes. It is very significant to note here that in traditional belief system women cannot become ancestors except men. While in Christianity, before a person becomes a saint, he or she must undergo certain rigours of processes laid down by the Church according to her dogma before becoming a saint. In fact, one cannot become an ancestor or a saint while he or she is still alive, one must die and that is why they are described as the 'living dead'. Thus, coming to Fr. Tansi's case, although he has not fully been canonized as a saint but he has excelled through certain hurdles or rigours of processes in making of a saint like the diocesan informative process, the Vatican Sacred congregation process and beatification. The only process that is remaining right now is for the Church with the power of the Holy See (the papacy) to declare him a saint in other to canonize him after just one elaborate miracle through his intercession. In African Traditional Religion, once a person dies, befitting funeral rites as part of prerequisites is absolutely imperative in that they are regarded as rites of passage by which the dead are installed or canonized automatically as ancestors. To these four requirements include: old age, offspring, good moral life, and befitting funeral rites, although there are certain societies who add a fifth requirement as good death.

Reverend Father Michael Cyprian Iwene Tansi has thus been deified, indeed being raised to the status of an ancestor or a saint agrees with Michael Nabofa's rationalization of deification theory thus:

In each case of deification, the deified person absorbs the power or spiritual qualities of an already existing deity. However, the deification theory does not say exactly from where men who made claims to be gods derived this conception of God in the first instance. More important still is that this theory does not really explain the origin of religion and it fails to tell us about how men first came about the idea of the divine. Deification is only a religious feature. It is only an expression of religious experience; it does not explain the origin of religion as such (1988:49).

The departed beloved ancestors and saints attained such status because of the divine essence in them, that is, the soul. In other words, it is not the physical body that is being deified rather, it is the divine essence that is being recognized and translated into the spiritual realm to which it really belongs. All that Fr. Tansi achieved he was able to achieve through the enablement of the divine essence of God in him. 


\section{References}

i. Arkin, M. 1989. One People - One Destiny: Some Explorations in Jewish Affairs. Hillcrest: Owen Burgess Publishers.

ii. Adejumo, A. 2013. Satire as Protest in An Indigenous Festival: A Case of Efe. International Journal of Humanities and Social Science Invention, vol. 2, 7. 43-50. Available From: www.ijhssi.org/papers/v2 (7) /Version-3/H0273043050.pdf. Accessed: 12 December 2013.

iii. Awolalu, J. 0. 1976.What is African Traditional Religion? 1-10, Available from: www.studiesincomparativereligion.com/uploads/articlepdfs/268.pdf. Accessed: 23 September 2012.

iv. Arinze, F. 1973. The Church and Nigerian Culture. Onitsha: Tabansi Press Ltd.

v. ASKEW, K. M. 2006. Sung and Unsung: Musical Reflections on Tanzania Postsocialisms. Africa: The Journal of the International African Institute, Vol. 76, No. 1, 2006, 15-43. Available From: http://muse.jhu.edu/journals/afr/summary/v076/76.1askew.html. Accessed: 13 March 2014.

vi. Aluede, C. O. 2005. 'Gender Roles In Traditional Musical Practice: A Survey of The Esan In Edo State, Nigeria'. Stud. Tribes Tribal 3. 1, 57-60.

vii. Bloch, M. 1987. The Ritual of the Royal Bath in Madagascar: The Dissolution of Death, Birth And Fertility into Authority cited in Rituals of Royalty: Power and Ceremonial in Traditional Societies (ed) by David Cannadine \& Simon Price (1987), Cambridge: Cambridge University Press. 271-297.

viii. Burns, J. M. 2005. My Mother Has A Television, Does Yours? Transformation and Secularization In An Ewe Funeral Drum Tradition. Oral Tradition, Vol. 20, No. 2. 300-319. Available From: http://muse.jhu.edu/journals/ort/summary/v020/20.2burns.html.Accessed: 11 January 2013.

ix. Bright, J. 1981. A History of Israel. London: SCM Press Ltd.

x. Chidester, D. 1992. Religions of South Africa. London: Routledge.

xi. Douillet, J. 1958. What is a Saint? New York: Hawthorn Books Publishers.

xii. Daniel, K. 2010. The Position of African Traditional Religion in Conflict Prevention. International Journal of Sociology and Anthropology 2. 2: 23-28. Available From:

www.academicjournals.org/Article/article1379416346_kasomo.pdf. Accessed: 6 January 2014.

xiii. Ejizu, C. I. 1986. Ofo, Igbo Ritual symbol, Enugu: Fourth Dimension Publishing co. Ltd.

xiv. Eyisi, V.M.C. 2010. Igbo History [With Bible References]. Onitsha: Chuvic Publishers.

xv. Ekeke, E. C. 2013. African Traditional Religion: A Conceptual and Philosophical Analysis. 1-18. Lumina, Vol. 22, No. 2, ISSN 2094-1188. Available From: lumina.hnu.edu.ph/articles/(s)ekekeOct11pdf. Accessed: 2 January 2014.

xvi. Ekeh, P. P. 1975. Colonialism And The Two Publics In Africa: A Theoretical Statement. Comparative Studies In Society And History, Vol. 17, No. 1. (Jan 1975); 91-112. Available From: http://links.jstor/.org/sici?sici=00104175\%28197501\%2917\%3A1\%3C91\%3ACATTPI\%3E2.0. C0\%3B2-\%23. Accessed: 12 March 2014.

xvii. Ekechi, F. K. 1976. A History of the Igbo People by Elizabeth Isichei [Review]. The American Historical Review, Vol. 81, No. 5 (Dec 1976), 1190-1191. Available From: http://www.jstor.org/stable/1853077. Accessed: 12 May 2014.

xviii. Falola, T. 2003. The Power of African Cultures. New York: University of Rochester Press.

xix. Hornby, A. S. 2010. Oxford Advance Learner's Dictionary: International Student's Edition. Oxford: Oxford University Press.

xx. Ikeanyibe, U. 2001. Agonies of Ndi-Igbo: A Chronicle of 150 Years of the Groanings of 40

xxi. Million People. Benin: Seed Sowers Publication.

xxii. Isichei, E.1976. A History of Igbo People. London: Macmillan Press Ltd.

xxiii.

xxiv.

xxV.

xxvi.

xxvii.

xxviii.

xxix. 2004. The Religious Traditions of Africa: A History. London: Praeger Publishers.

Idigo, F. C. 2001. Eri kingdom of An Igbo king From Israel. Lagos: X-Pose Communications Ltd.

Idigo, P. M. 1977. Our memoirs of the Reverend Father Michael Cyprian Tansi, Onitsha: Tabansi Press Ltd.

Idigo, M. C. M. 1955. The History of Aguleri. Lagos, Yaba-Lagos: privately printed.

1990. Aguleri History and culture. Lagos: Bantam Press Ltd.

Idowu, E. B. 1973. African Traditional Religion: A Definition, London, SCM Press Ltd.

Igwah, R; Okoye, E; Chinwuba, O; Nnechi, J; Nnamah, P; Chikwenze, R; Ikem, E; Ejimofor, G

\& Chieze, C. 2014. 'Aguleri Is the Ancestral Home of The Igbos, Not Nri'. Available

From: www.nairaland.com/1813782/aguleri-ancestral-home- igbos-not. Accessed: 18

July 2014.

xxxiv. Koskoff, E. 1989. An Introduction To Womem, Music, And Culture, in Women and Music in Cross-Cultural perspective (ed) by Ellen Koskoff, Urbana and Chicago: University of IIIinios Press. 1-23.

xxxv. Madukasi, F. C. 1999. 'The cult of saints And Ancestors: Rev. Fr. Cyprian Michael Iwene Tansi, as a Case Study'. Unpublished B. A essay, Department of Religious Studies, University of Ibadan.

xxxvi. Mbiti, J. S. 1969. African Religions and Philosophy. London: Heinemann Educational Books Ltd.

xxxvii. 1970. Concepts of God in Africa, London: S.P.C.K. 1977. Introduction to African Religion, London:

Heinemann Educational Books, Ltd

xxxviii. Metuh, E. I. 1987. Comparative Studies of African Traditional Religions. Onitsha: IMICO Publishers Ltd. 
xxxix. Macgaffey, W. 1994. Kimbanguism And The Question of Syncretism In Zaire cited in Religion In Africa: Experience and Expression (ed) by Thomas D. Blakely, Walter E. A. Van Beek, \& Dennis L. Thomson (1994), London: Heinemann. 241-256.

xl. Mcadams, D. P. 1988. Power, Intimacy, and The Life Story: Personological Inquiries Into Identity. New York \& London: The Guilford Press.

xli. Nabofa, M. Y. 1988. Introduction of the Study of Religion. Ibadan: Agoro Publishing Company.

xlii. 1994. Symbolism in African Traditional Religion, Ibadan: Paperback Publishers Ltd.

xliii. 1994. Religious Communication: A study in African Traditional Religion, Ibadan: Daystar Press .

xliv. Nwoye, A. 2007. The Practice of Interventive Polygamy In Two Regions of Africa: Background, Theory And Techniques. Dialectical Anthropology, Vol. 31, No. 4 (2007), 383-421. Available From: http://www.jstor.org/stable/29790800. Accessed: 6 April 2014.

xlv. Nzewi, M; Anyahuru, I; \& Ohiaraumunna, T. 2001. Beyond Song Texts-The Lingual Fundamentals of African Drum, Research In African Literature, vol. 32, no.2.89-104. Available From: http:/muse.jhu.edu/journals/at/summary/V032/32.2.nzewi.html. Accessed: 10 November 2012.

xlvi. Nwokocha, E. E. 2007. Male-Child Syndrome And The Agony of Motherhood Among the Igbo of Nigeria. International Journal of Sociology of the Family, Vol, 33, No. 1, Aging in Asia (Spring 2007), 219-234. Available From: http://www.jstor.org/stable/23070711. Accessed: 7 April 2014.

xlvii. Nwosu, E. E. 1998. Spiritual Heritage: The Venerable Servant of God Fr. Cyprian Michael Iwene Tansi. Jos: Trans African Links Inc.

xlviii. Nfah-Abbenyi, J. M. 2005. Gender, Feminist Theory, And Post-Colonial (Women's) Writing,cited in African Gender Studies: A Reader (ed) by Oyeronke Oyewumi 2005, New York: Palgrave Macmillan. 259-278.

xlix. News Letter, No.2, December, 1983.

l. News Letter, No. 4, December, 1983.

li. Omoregie, B.S. 1989. The Man Eri; University magazine, Vol. 112, The institute of African Studies, University of Ibadan, Ibadan, 41-43.

lii. Omoregbe, J. I. 1993. Ethics: A Systematic and Historical Study, Lagos: Joja Educational Press Ltd.

liii. Obi, C.A; 1985. The French Pioneers 1885-1905 cited in A Hundred Years of The Catholic Church in Eastern Nigeria1885-1985 by Obi, C.A; Nwosu, V; Eke, C; Onwubiko, K. B. C \& Okon, F. E. (ed) by Obi, C. A. Onitsha: Africana-Fep Publishers Ltd. 27-105.

liv. Onwuejeogwu, M. A. 1981. An Igbo Civilization: Nri Kingdom and Hegemony. London:

lv. Ethnographica Ltd.

lvi. Okafor, R .C. 1998. Nigerian Organology And Classification of African Musical Instruments cited in Nigerian People's and Culture for Higher Education. (eds) by R. C. Okafor \& L. N. Emeka (1998) Enugu: New Generation Ventures Limited. 173-192.

lvii. Ojukwu, O. C. 1998. Toward A Greater Nigeria: The Harsh Realities, Selected Speeches of Dim Emeka Odumegwu Ojukwu 1982-1998. (Compiled) by Okorie k. k \& Ugochukwu, S. S. C, U.S.A: Good Hope Enterprises, Inc.

lviii. Onunwa, U. R. 2002. Christian Missionary and Their Influence on Eastern Nigeria cited in The Gods In Retreat: Continuity And Change In African Religion (ed) by Emefie Ikenga Metuh (2002), Enugu: Fourth Dimension Publishers.67-89.

lix. Ogbu, U. K. 2010. The Collected Essays of Ogbu Uke Kalu: African Pentecostalism: Global Discourses, Migration, Exchange And Connections. Vol. 1, (Edited) by Wilhelmina J. Kalu, Nimi Wariboko, \& Toyin Falola (2010), Eritrea: African World Press Inc.

lx. 2010. The Collected Essays of Ogbu Uke Kalu: Christian Missions In Africa: Success, Ferment And Trauma. Vol. 2, (Edited) by Wilhelmina J. Kalu, Nimi Wariboko, \& Toyin Falola (2010), Eritrea: African World Press Inc.

lxi. Ofili, C. N. 1998. Still on Saints. The Guardian Newspaper, July 5, p. 27.

lxii. Ojigbo, 1998. Pope John Paul's Second Coming. The Guardian Newspaper, March, 15, p. 15.

lxiii. Oshitelu, G. A. 2002. Reason and Belief: Issues in Contemporary Godlessness. Ibadan: Hope Publications.

lxiv. Ozah, M. A. 2006. 'The Iwali Child Queen Dance of Ogoja Nigeria'. The World of Music, Vol. 48,No.1, Music and Childhood: Creativity, Socialization, and Representation (2006), 67-82. Available From: http://www.jstor.org/stable/41699679. Accessed: 27 October 2014.

lxv. Popkin, R. H. \& Stroll, A. 1981. Philosophy Made Simple, Made Simple (eds), Book Series. London: Heinemann.

lxvi. Pinkerton, S. 2011. Ralph Ellison Righteous Riffs: Jazz, Democracy, and the Sacred. African American Review, Vol. 44, No. 1-2, (Spring/Summer, 2011), 185-206. Available From:

http://muse.jhu.edu/journals/afa/summary/v044/44.1-2.pinkerton.html. Accessed: 1 January 2013.

lxvii. Sofola, J. A. 1973. African culture and the African Personality, Ibadan: African Resources Publishers Co.

lxviii. Shaw, T. 1975. 'Those Igbo-Ukwu Radio-Carbon Dates: Facts, Fictions and Possibilities'. The Journal of African History, Vol. 16, No, 4 (1975), 503-517. Available From:http://www.jstor.org/stable/180494. Accessed: 16 July 2014.

lxix. Schipper, K. 1993. The Taoist Body [Translated] by Karen. C. Duval. Berkeley \& Los Angeles: University of California Press.

lxx. Tapper, N. 1991. Bartered Brides: Politics, Gender and Marriage In An Afghan Tribal Society. Cambridge: Cambridge University Press. 
lxxi. Trinitas, Onitsha Archdiocese, Vo. 9, No. 26 March, 1998.1

lxxii. Udo, B. E. O. 2008. Religion and Society: Socio-Ethical, Religious and Cultural Life of Ibibio People. Aba: Okman.

lxxiii. Wareing, G. 1998. Sorrow Will Not Kill Me. Onitsha: Visio AD, Inc Ltd.

lxxiv. Xrydz - Eyutchae, C. 1986. 'Anambra Is the Ancestral Home of the Igalas', Daily Star Press Ltd, Enugu: August $11,18$.

lxxv. Young, R. J. C. 2003. Post-Colonialism: A Very Short Introduction. New York: Oxford University Press. 